\title{
Phosphate Removal by Adsorption to Activated Carbon
}

\author{
Keito Boki and Seiki Tanada \\ Faculty of Pharmaceutical Sciences, Kinki University, Osaka \\ Tamotsu Miyoshi, Ryoji Yamasaki, Nobuhiro Ohtani and Takamichi Tamura \\ Department of Publich Health, School of Medicine, The University of Tokushima, Tokushima
}

\section{INTRODUCTION}

The concentrations of phosphorus, nitrogen, and other nutritive elements in lakes, bays and inland seas are increased because domestic waste water, the second-step treated water from sewage treatment facilities, and the industrial waste water from some plants flow continuously into them. As a result, the waters are eutrophicated and the water quality is lowered, which results in unpalatable drinking water, red lakes, and various other problems. In typical cases, phosphorus acts as an accelerating substance for the growth of algae ${ }^{1}$. Furthermore, phosphorus concentration is used as an indicator of the degree of eutrophication ${ }^{2)}$.

Either or both of the nutritive elements, i.e., phosphorus and nitrogen, should be removed to prevent this eutrophication. It is difficult to remove nitrogen to a sufficiently low concentration by the ammonia stripping process or the activated sludge process ${ }^{3}$. Therefore, prevention of eutriphication requires the effective removal of phosphorus.

The methods for removing phosphorus include the chemical coagulation process, the adsorption process, the ion exchange process, the crystallization process, and the biological dephosphorization process. The coagulation process, which is most widely used, has problems as a result of the cost of chemical injection and the profuse generation of sludge. In the crystallization process and the biological dephosphorization process, on the other hand, there are many technical problems to be solved.

Though recently an activated carbon adsorption process is often incorporated in the second-or the third-step liquid-waste treatment, there are very few studies on phosphate adsorption to activated carbon. This may be because activated carbon has been reported to be unsuitable for the adsorption of inorganic ions or lower alcohols"). However, now that this process is utilized in practice, it is necessary to obtain detailed data on the properties of phosphate adsorption onto activated carbon.

Basic studies on the adsorption treatment of phosphate-containing waste water have been carried out using adsorbents other than activated carbon, such as synthetic aluminium silicate ${ }^{5}$, hydroxyapatite ${ }^{6}$, and ion-exchange resin". These studies have shown that the adsorption of phosphate to such adsorbents proceeds through a chemical adsorption mechanism ${ }^{5 \sim 7}$.

In the present study, the adsorption equilibrium and the adsorption rate of phosphate to activated carbon are examined to obtain basic data on the adsorption-removal treatment of phosphate-containing waste water by activated carbon. The phosphate concentrations were adjusted within the range of those in the first-or the second-step treated waters). The adsorbates used are $\mathrm{H}_{3} \mathrm{PO}_{4}, \mathrm{NaH}_{2} \mathrm{PO}_{4}, \mathrm{KH}_{2} \mathrm{PO}_{4}$, and $\mathrm{H}_{6} \mathrm{P}_{4} \mathrm{O}_{13}$, which have been reported to be contained in these types of treated water").

In addition, the relationships of the pore size distribution of activated carbon to the amount of adsorbate adsorbed and the intraparticle diffusivity are clarified.

\section{MATERIALS AND METHODS}

1 Materials

Activated carbons used were obtained from commercial sources; namely, activated carbon No.1, 
Bamberg Co. ; activated carbon No. 2, Takeda Chemical Ind., Ltd. (Shirasagi) ; activated carbon No. 3, Nakarai Chemicals, Ltd. ; activated carbon No. 4, Takeda Chemical Ind., Ltd. (Molecular Sieve Carbon). The particle sizes ranged from 4 to 7 mesh. The physical properties are shown in Table 1.

Adsorbates used were $\mathrm{H}_{3} \mathrm{PO}_{4}, \mathrm{NaH}_{2} \mathrm{PO}_{4} \cdot 2 \mathrm{H}_{2} \mathrm{O}, \mathrm{KH}_{2} \mathrm{PO}_{4}$, and $\mathrm{H}_{6} \mathrm{P}_{4} \mathrm{O}_{13}, \mathrm{H}_{3} \mathrm{PO}_{4}, \mathrm{NaH}_{2} \mathrm{PO}_{4} \cdot 2 \mathrm{H}_{2} \mathrm{O}$, and $\mathrm{KH}_{2} \mathrm{PO}$, were extra-pure reagents (Wako Pure Chemical Ind., Ltd), and $\mathrm{H}_{6} \mathrm{P}_{4} \mathrm{O}_{13}$ was of reagent grade (Wako Pure Chemical Ind., Ltd.). They were used without further purification.

2 Methods

2.1 Procedure for equilibrium isotherm

Phosphate solution was prepared by dissolving a given amount of phosphate into distilled water. A weighed amount of activated carbon, $0.5 \mathrm{~g}$, was shaken at the rate of $7.6 \mathrm{~m} / \mathrm{min}$ with $100 \mathrm{~m} l$ of phosphate solution of $c a .10$ to $2000 \mathrm{ppm}$ at the constant temperature of $30^{\circ} \mathrm{C}$. It took 4 days to attain equilibrium adsorption. After equilibration, the phosphate concentration in the supernatant solution was determined by the molybdenum blue method ${ }^{10)}$. After the equilibration period, the $\mathrm{pH}$ value of the filtrate was measured by using the Horiba $\mathrm{F}-7 \mathrm{pH}$ meter.

\subsection{Adsorption rate}

The adsorption rate of phosphate was determined according to the batch adsorption ${ }^{11}$. A weighed amount of activated carbon, $4.0 \mathrm{~g}$, was placed in a flask containing distilled water, and the suspension was boiled for $1 \mathrm{hr}$ to displace the air in the pores of the activated carbon with water. The activated carbon impregnated with water was placed in $800 \mathrm{~m} l$ of a stirred phosphate solution $\left(5.0 \times 10^{-4} \mathrm{mmol} / \mathrm{m} l\right)$ at $30^{\circ} \mathrm{C}$. The stirring rate, $400 \mathrm{rpm}$, was confirmed to be the condition of rate-determination by intraparticle diffusion. One $\mathrm{m} l$ of the supernatant solution was removed with a $1-\mathrm{m} l$ pipette at regular intervals. The amount of phosphate adsorbed was determined by the isotherm method. The adsorption rate experiment was repeated three times to check the reproducibility.

2.3 Pore size distribution and specific surface area

The pore size distribution of activated carbon was measured by the method described previously ${ }^{12}$. The specific surface area of activated carbon was measured with the Blunauer, Emmett, and Teller apparatus ${ }^{13)}$ using nitrogen gas as an adsorbate at liquid nitrogen temperature. Before adsorption runs, the adsorbent was dried at $110^{\circ} \mathrm{C}$ for $2 \mathrm{hrs}$ at $1 \times 10^{-3}$ Torr. A value of $16.2 \AA^{2}$ was taken for the area occupied by a nitrogen molecule at the temperature of liquid nitrogen.

\subsection{Surface $\mathrm{pH}$}

The surface $\mathrm{pH}$ value of activated carbon was obtained by measuring the $\mathrm{pH}$ of the filtrate of activated carbon suspension in distilled water.

\section{RESULTS}

\section{Adsorption isotherm}

Figures 1-4 show the adsorption isotherms of $\mathrm{H}_{3} \mathrm{PO}_{4}, \mathrm{NaH}_{2} \mathrm{PO}_{4}, \mathrm{KH}_{2} \mathrm{PO}_{4}$, and $\mathrm{H}_{6} \mathrm{P}_{4} \mathrm{O}_{13}$ on activated carbon. Generally, the adsorption isothermal plot of an adsorbate dissolved in water forms a straight line in the $\log \mathrm{Q}-\log \mathrm{C}$ coordinate system as shown by the Freundlich's adsorption isothermal equation,

$$
\log Q=n \log C+\log f
$$

where $Q$ is the amount adsorbed, $C$ is the equilibrium concentration, and $n$ and $f$ are constants. In all adsorbate used the relationship between $\log Q$ and $\log C$ was represented by Equation (1) as shown in Figs. 1-4. Thus, linear equations were formulated by the least squares method and the values of $n$ and $f$ were determined from them.

Some of the adsorption isotherms of phosphate on activated carbon had a flection while the others formed a straight line. For activated carbon samples Nos. 1, 3, and 4, the flection points were in the neighborhood of $\log \mathrm{C}=-3.0$. For activated carbon No. 2, on the other hand, the relationship between $\log$ $Q$ and $\log C$ was expressed by a straight line over the entire concentration range examined.

2 Relation between equilibrium adsorption and $\mathrm{pH}$ value

The influence of the $\mathrm{pH}$ value on the amount adsorbed was investigated using activated carbon No. 2 , for which the amount adsorbed was the greatest. The $\mathrm{pH}$ values of the solution were adjusted with 


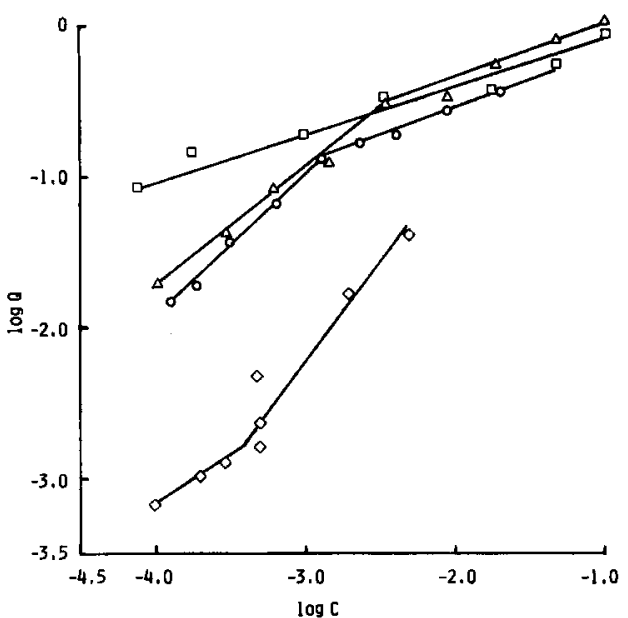

Fig. 1 Adsorption isotherms of $\mathrm{H}_{3} \mathrm{PO}$, on activated carbon. $\mathrm{Q}$ : amount adsorbed $(\mathrm{mmol} / \mathrm{g}), \mathrm{C}$ : equilibrium concentration (mmol/ml), O: No. 1, $\square:$ No. 2, $\triangle:$ No. $3, \diamond:$ No. 4.

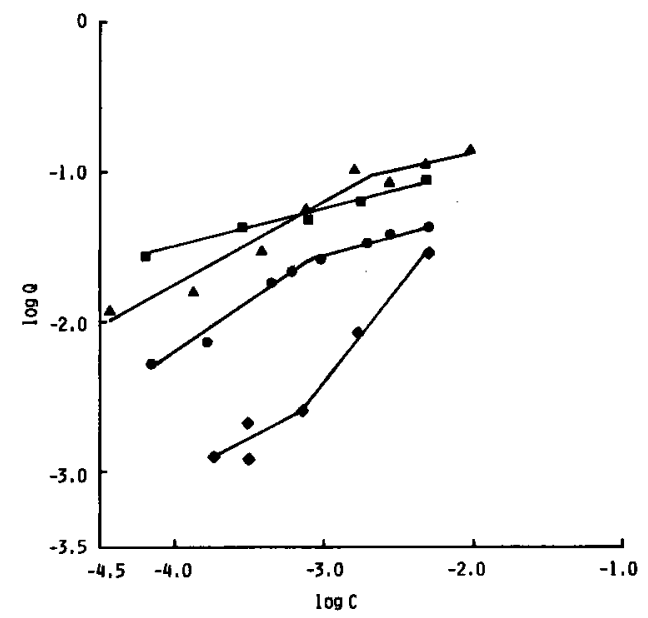

Fig. 3 Adsorption isotherms of $\mathrm{KH}_{2} \mathrm{PO}$, on activated carbon. $\mathrm{Q}$ : amount adsorbed $(\mathrm{mmol} / \mathrm{g})$, C: equilibrium concentration $(\mathrm{mmol} / \mathrm{ml}), 0:$ No. 1 , $\square:$ No. 2, $\triangle$ : No. 3, : No. 4.

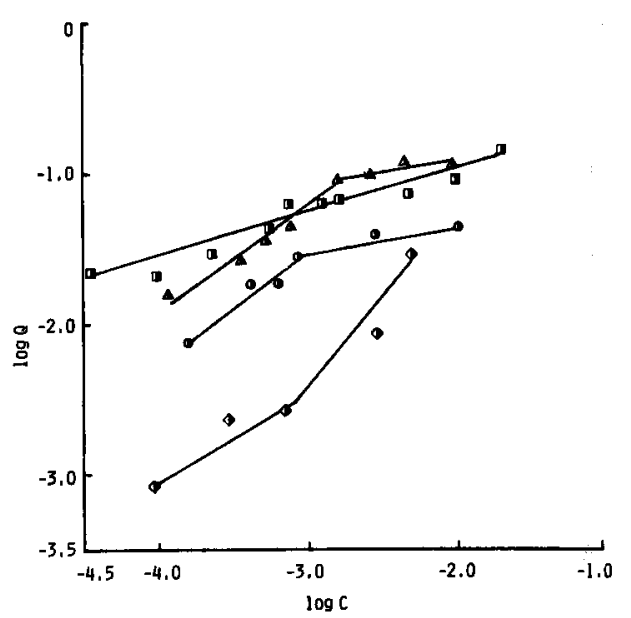

Fig. 2 Adsorption isotherms of $\mathrm{NaH}_{2} \mathrm{PO}_{4}$ on activated carbon. $Q$ : amount adsorbed $(\mathrm{mmol} / \mathrm{g}$ ), $\mathrm{C}$ : equilibrium concentration $(\mathrm{mmol} / \mathrm{m} l), \mathbf{O}: \mathrm{No} .1$, [ : No. 2, $4:$ No. 3, : No. 4.

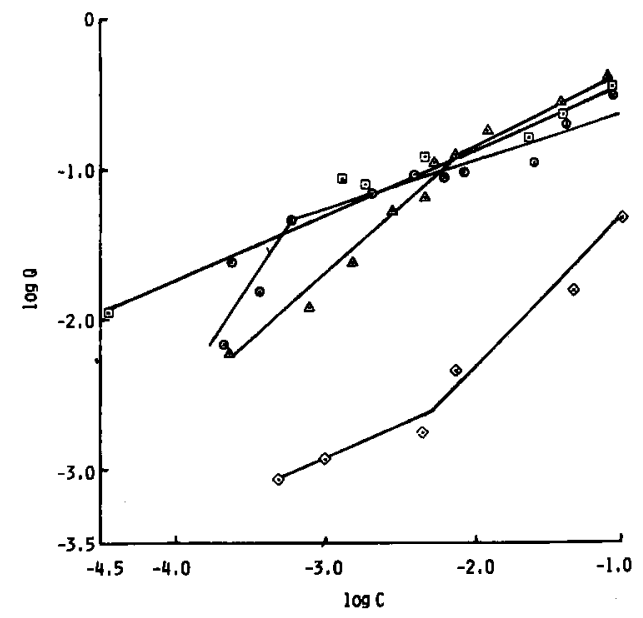

Fig. 4 Adsorption isotherms of $\mathrm{H}_{6} \mathrm{P}_{4} \mathrm{O}_{13}$ on activated carbon. $\mathrm{Q}$ : amount adsorbed $(\mathrm{mmol} / \mathrm{g}), \mathrm{C}$ : equilibrium concentration $(\mathrm{mmol} / \mathrm{m} l), \odot:$ No. $1, \square:$ No. 2, $\triangle:$ No. 3, $\odot:$ No. 4.

Table 1 Properties of activated carbon used.

\begin{tabular}{|c|c|c|c|c|c|}
\hline $\begin{array}{c}\text { Activated } \\
\text { carbon No. }\end{array}$ & $\begin{array}{c}\text { Specific surface } \\
\text { area }\left(\mathrm{m}^{2} / \mathrm{g}\right)\end{array}$ & $100 \AA \geqq r$ & $\begin{array}{l}\text { volume ( } \mathrm{r} \\
12 \AA \geqq \mathrm{r}\end{array}$ & $9 \AA \geqq r$ & Surface $\mathrm{pH}$ \\
\hline 1 & 1384.5 & 0.7759 & 0.4175 & 0.1175 & 6.53 \\
\hline 2 & 938.3 & 0.6371 & 0.4350 & 0.3150 & 6.38 \\
\hline 3 & 378.0 & 0.6645 & 0.2900 & 0.1675 & 8.74 \\
\hline 4. & 350.9 & 0.2612 & 0.1250 & 0.0550 & 5.66 \\
\hline
\end{tabular}


hydrochloric acid or sodium hydroxide for $\mathrm{H}_{3} \mathrm{PO}_{4}$ and $\mathrm{NaH}_{2} \mathrm{PO}_{4}$, and with hydrochloric acid or potassium hydroxide for $\mathrm{KH}_{2} \mathrm{PO}$. The initial concentration of phosphate solution was $1.0 \times 10^{-3} \mathrm{mmol} / \mathrm{ml}$. The results are shown in Fig. 5 . The amount adsorbed was the greatest in the weak acid range of $\mathrm{pH} 5$ -6 .

\section{Rate of adsorption}

In the present study the intraparticle diffusivity, which is a characteristic of the adsorption rate, was measured by the method of batch adsorption ${ }^{11}$. The adsorption rate was determined from the reduction in adsorbate concentration caused during the adsorption process, and reproducible observation could be made rather easily with a system where intraparticle diffusivity was the rate-determining process.

The relationships between phosphate concentration and adsorption time are shown in Figs. 6-9. It can be seen from these results that for al! adsorbates the concentration reduction rate is the highest in activated carbon No. 3 .

The intraparticle diffusivity $\left(D_{1}{ }^{\prime}\right)$ can be calculated by the following equations.

$$
\begin{aligned}
& \mathrm{E}=\frac{\mathrm{C}_{0}-\mathrm{C}_{t}}{\mathrm{C}_{0}-\mathrm{C}_{\infty}} \ldots \ldots . . . \\
& \overline{\mathbf{a}}=\frac{\mathrm{W} \cdot \mathrm{f}}{\mathrm{V}} \cdot \frac{\mathrm{C}_{0}^{n}-\mathrm{C}_{\infty}^{n}}{\mathrm{C}_{0}-\mathrm{C}_{\infty}} \\
& \mathrm{k}=\frac{10 \mathrm{D}_{\mathrm{i}}{ }^{2}}{\overline{\mathrm{R}}^{2}}
\end{aligned}
$$

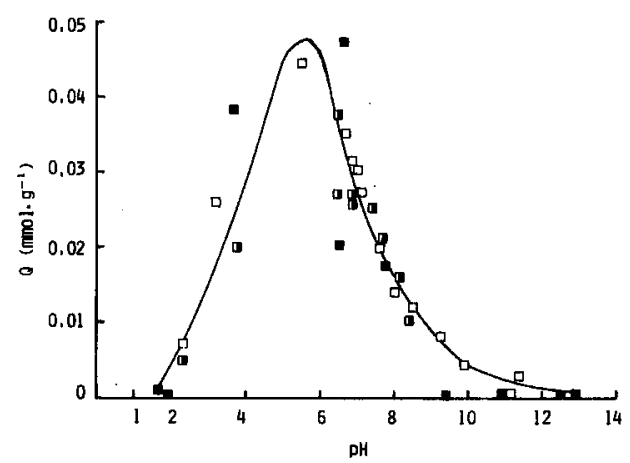

Fig. 5 Effect of equilibrium pH on amount of phosphate adsorbed on activated carbon No. 2. Q : amount adsorbed, $\mathrm{pH}$ : equilibrium $\mathrm{pH}, \square: \mathrm{H}_{3} \mathrm{PO}_{4}$, 口: $\mathrm{NaH}_{2} \mathrm{PO}_{4}, \mathbf{\square}: \mathrm{KH}_{2} \mathrm{PO}_{4}$, initial concentration of phosphate : $1.0 \times 10^{-3} \mathrm{mmol} / \mathrm{m} l$.

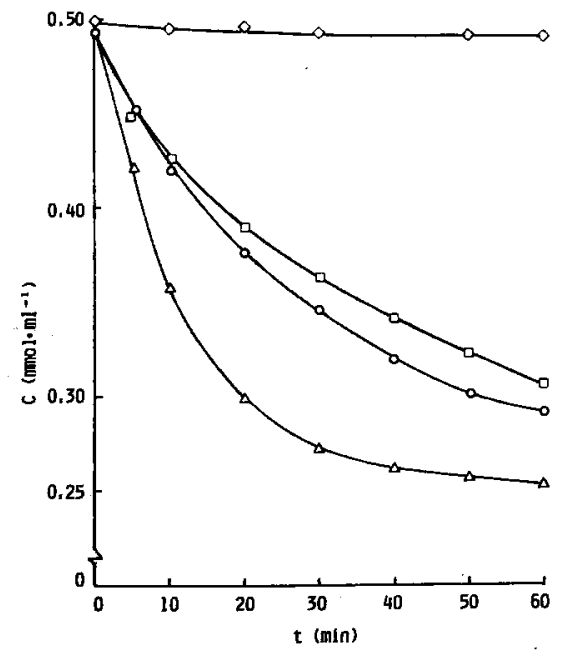

Fig. 6 Change in concentration of $\mathrm{H}_{3} \mathrm{PO}_{4}$ with adsorption time for activated carbon. $\mathrm{C}$ : con centration of $\mathrm{H}_{3} \mathrm{PO}_{4}, \mathrm{t}$ : adsorption time, $\mathrm{O}:$ No. 1 , $\square:$ No. 2, $\Delta:$ No. 3, $\diamond:$ No. 4 .

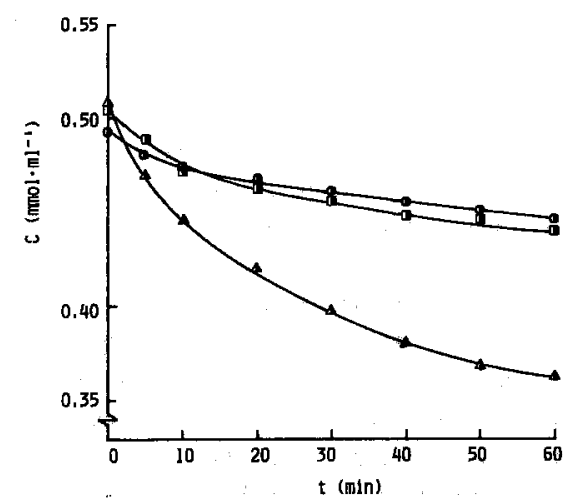

Fig. 7 Change in concentration of $\mathrm{NaH}_{2} \mathrm{PO}_{4}$ with adsorption time for activated carbon. $\mathrm{C}$ : concentration of $\mathrm{NaH}_{2} \mathrm{PO}_{4}, \mathrm{t}:$ adsorption time, $\mathrm{O}$ : No. 1, $\mathbf{C}:$ No. $2, \boldsymbol{\Delta}:$ No. 3. 


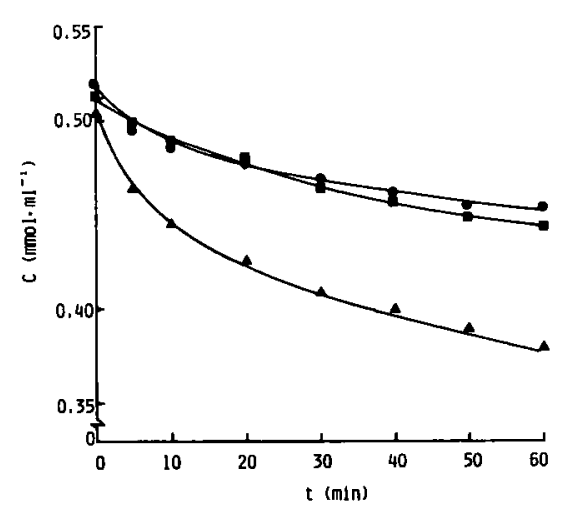

Fig. 8 Change in concentration of $\mathrm{KH}_{2} \mathrm{PO}_{4}$ with adsorption time for activated carbon. $\mathrm{C}$ : concentration of $\mathrm{KH}_{2} \mathrm{PO}_{4}, \mathrm{t}$ : adsorption time, : No. 1, 口: No. 2, $\mathbf{A}$ : No. 3.

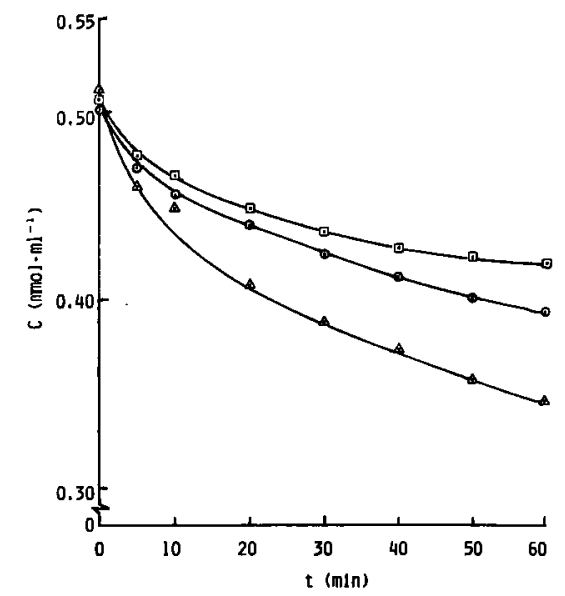

Fig. 9 Change in concentration of $\mathrm{H}_{6} \mathrm{P}_{4} \mathrm{O}_{13}$ with adsorption time for activated carbon. $\mathrm{C}$ : concentration of $\mathrm{H}_{6} \mathrm{P}_{4} \mathrm{O}_{19}, \mathrm{t}$ : adsorption time, $\odot:$ No. 1 ,

$\nabla:$ No. 2, $\triangle:$ No. 3 .

$E$ is the fractional approach to equilibrium; $C_{0}$ is the initial concentration; $C_{t}$ is the concentration at elapsed time ; $\mathrm{C}_{\infty}$ is the equilibrium concentration of the solution; $\overline{\mathrm{a}}$ is the average capacity ratio defined by Equation (3) ; $\mathrm{W}$ is the weight of the adsorbent; $\mathrm{f}$ is the coefficient in the Freundlich equation; $\mathrm{V}$ is the volume of the solution; $n$ is the exponent in the Freundlich equation; $k$ is the rate constant ; $R$ is the radius of adsorbent particles; $t$ is the elapsed time. The relationship between $E$, $\bar{a}$, and $k$ has been presented ${ }^{14}$. Since $\mathrm{E}$ and $\bar{a}$ can be calculated by substituting measured values in Equations (2) and (3). kt is determined from the graph of $E$ and $k t$ for the various values of $\bar{a}^{14)}$. The relation between $k t$ and $t$ thus determined is shown in Figs. 10-13. Since $k$ is expressed as the gradient of the straight lines, $D_{1}^{\prime}$ can be calculated by Equation (4). The values of $D_{1}^{\prime}$ are listed in Table 2. In all adsorbates, the $D_{1}^{\prime}$ values of phosphate adsorbed on activated carbon No. 3 are 5-30 times as large as those for the other activated carbons.

\section{DISCUSSION}

\section{Adsorption isotherm}

It was reported that the concentrations of phosphate in the first-and the second-step treated water from sewage treatment facilities are in the ranges of $0.9-1.5 \times 10^{-2} \mathrm{mmol} / \mathrm{m} l(\log \mathrm{C}=-2.0--1.8)$ and $2.0 \times 10^{-5}-2.3 \times 10^{-3} \mathrm{mmol} / \mathrm{m} l(\log \mathrm{C}=-4.7--2.6)$, respectively ${ }^{8}$. The phosphate concentrations used in the present examination on the isotherm were in the concentration range of the first-and the secondstep treated water.

In every adsorbate examined, the amount adsorbed on activated carbon No. 3 was greater than that adsorbed to the other activated carbons in the phosphate concentration range of the first-step treated water. For activated carbon No. 2, on the other hand, the amount of each adsorbate adsorbed was greater than that for the other activated carbon samples in the phosphate concentration range of the second-step treated water. These results show that activated carbons No. 3 and No. 2 are the most suitable adsorbents for phosphate removal from the first-and the second-step treated water, respectively.

The amounts of $\mathrm{NaH}_{2} \mathrm{PO}_{4}$ and $\mathrm{KH}_{2} \mathrm{PO}_{4}$ adsorbed were $1 / 3-3 / 5$ of those of $\mathrm{H}_{3} \mathrm{PO}_{4}$ over the entire range of phosphate concentration, except for the experimental runs with activated carbon No. 4. It was reported that the amount of phosphate adsorbed on hydroxyapatite is increased by adding $\mathrm{Na}^{+}$or $\mathrm{K}^{+6}$ ). The present results, on the other hand, show that the amount of phosphate adsorbed on activated carbon 


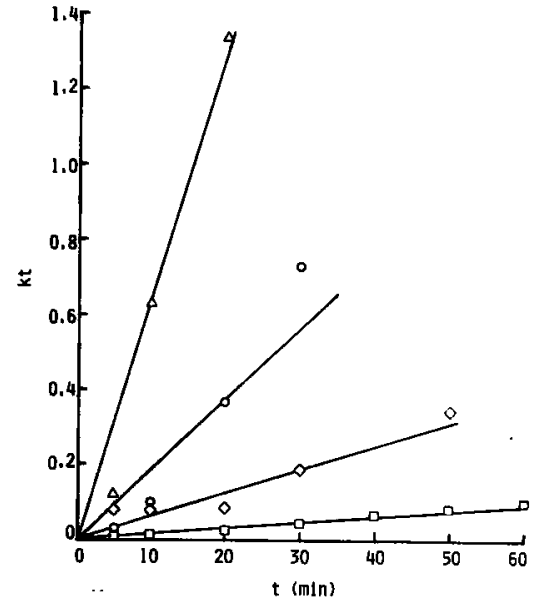

Fig. 10 Relationships between $k t$ and $t$ for adsorption of $\mathrm{H}_{3} \mathrm{PO}$, on activated carbon. $\mathrm{k}$ : rate constant, $\mathrm{t}$ : adsorption time, $\mathrm{O}:$ No. $, \square:$ No. $2, \Delta$ : No. 3, $\diamond:$ No. 4.

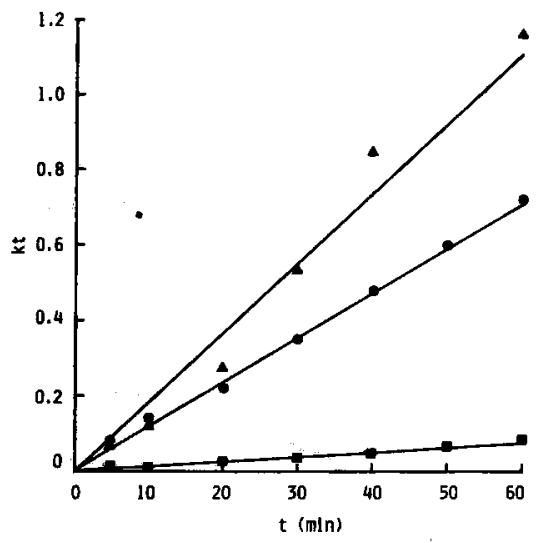

Fig. 12 Relationships between $k t$ and $t$ for adsorption of $\mathrm{KH}_{2} \mathrm{PO}$, on activated carbon. $\mathrm{k}$ : rate constant, $\mathrm{t}$ : adsorption time, : No. 1, $\mathbf{\square}:$ No. 2, $\boldsymbol{\Delta}$ : No. 3.

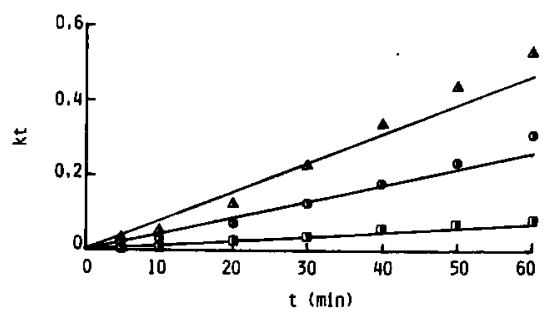

Fig. 11 Relationships between $k t$ and $t$ for adsorption of $\mathrm{NaH}_{2} \mathrm{PO}_{4}$ on activated carbon. $\mathrm{k}$ : rate constant, $\mathrm{t}$ : adsorption time, $\square$ : No.1, $\mathbf{\square}:$ No. 2 , $\Delta$ : No. 3 .

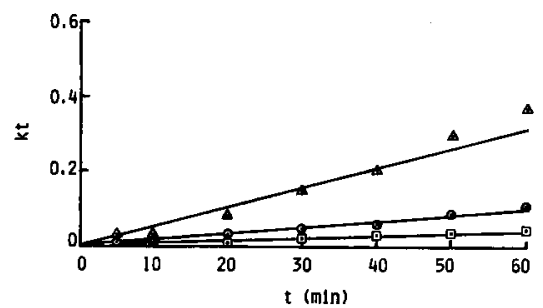

Fig. 13 Relationships between $k t$ and $t$ for adsorption of $\mathrm{H}_{6} \mathrm{P}_{4} \mathrm{O}_{13}$ on activated carbon. $\mathrm{k}$ : rate constant, $\mathbf{t}$ : adsorption time, $\odot:$ No. $1, \bullet:$ No. $2, \triangle$ : No. 3.

Table 2 Intraparticle diffusivity of phosphate on activated carbon.

\begin{tabular}{crccc}
\hline \multirow{2}{*}{$\begin{array}{c}\text { Activated } \\
\text { carbon No. }\end{array}$} & \multicolumn{4}{c}{$\mathrm{D}^{\prime}\left(\mathrm{cm}^{2} / \mathrm{sec}\right)$} \\
\cline { 2 - 5 } & $\mathrm{H}_{3} \mathrm{PO}_{4}$ & $\mathrm{NaH}_{2} \mathrm{PO}_{4}$ & $\mathrm{KH}_{2} \mathrm{PO}_{4}$ & $\mathrm{H}_{6} \mathrm{P}_{4} \mathrm{O}_{13}$ \\
\hline 1 & $11.0 \times 10^{-7}$ & $6.5 \times 10^{-7}$ & $2.2 \times 10^{-7}$ & $0.9 \times 10^{-7}$ \\
2 & $0.8 \times 10^{-7}$ & $0.6 \times 10^{-7}$ & $0.8 \times 10^{-7}$ & $1.4 \times 10^{-7}$ \\
3 & $24.0 \times 10^{-7}$ & $7.9 \times 10^{-7}$ & $3.8 \times 10^{-7}$ & $2.7 \times 10^{-7}$ \\
4 & $4.4 \times 10^{-7}$ & - & - & - \\
\hline
\end{tabular}

decreases in the presence of $\mathrm{Na}^{+}$or $\mathrm{K}^{+}$. This indicates that the adsorption of phosphate on activated carbon is a physical process rather than an electrostatic or chemical process.

The amounts of $\mathrm{NaH}_{2} \mathrm{PO}_{4}$ and $\mathrm{KH}_{2} \mathrm{PO}_{4}$ adsorbed were nearly the same over the entire concentration range examined. It has been suggested that the adsorption of phosphate on hydroxyapatite was affected by the ion sizes of $\mathrm{Na}^{+}$and $\mathrm{K}^{+6}$ ), while the present results show that no difference in adsorption capacity was brought about by $\mathrm{Na}^{+}$and $\mathrm{K}^{+}$when activated carbon was used. It can be seen from these findings that the electrostatic forces and the ion sizes of $\mathrm{Na}^{+}$and $\mathrm{K}^{+}$have an influence on the adsorption of phosphate on activated carbon.

Some of the adsorption isotherms of phosphate on activated carbon had flections while the others 
formed straight lines. It has been suggested that the inflection in the Freundlich's adsorption isotherm of phosphate on synthetic aluminium silicate is formed because the adsorption mechanisms are different in the higher and the lower regions of phosphate concentration ${ }^{15}$.

2 Relation of equilibrium adsorption to pore size distribution

As a rule, the equilibrium adsorption of phosphate on activated carbon is affected by various properties of activated carbon and by the concentration and $\mathrm{pH}$ value of the sample solution. The relation of the amount adsorbed at $1 \times 10^{-3} \mathrm{mmol} / \mathrm{ml}$ (Figs. 1-4) to the specific surface area (Table 1) of activated carbon was examined; however, no correlation between them was observed. This is consistent with the amount of $\mathrm{KH}_{2} \mathrm{PO}_{4}$ adsorbed to the specific surface area of silica-alumina ${ }^{5}$. Generally, the specific surface area is measured including the surfaces of small pores and large pores. The amount adsorbed and the specific surface area indicate that adsorption of phosphate would tend to occur in small pores rather than large ones.

The pore volume for pores with radii of less than $100 \AA$ was measured. No correlation was observed between the amount adsorbed at $1 \times 10^{-3} \mathrm{mmol} / \mathrm{ml}$ of phosphate (Figs. 1-4) and the pore volume below the pore radius of $100 \AA$ (Table 1). This suggests that the adsorption of phosphate on activated carbon takes place in the smaller pores rather than in the pores with radii up to $100 \AA$.

Figure 14 shows the pore size distribution curves for pores with radii of $50 \AA$ or less. For adsorbates of small molecular size such as $\mathrm{H}_{3} \mathrm{PO}_{4}, \mathrm{NaH}_{2} \mathrm{PO}_{4}$, and $\mathrm{KH}_{2} \mathrm{PO}_{4}$, activated carbon of greater adsorption capacity (No. $2>$ No. $3>$ No. $1>$ No. 4 ) in the low concentration range of $3.0 \times 10^{-5}-1.0 \times 10^{-3} \mathrm{mmol} / \mathrm{m} l$ $(\log \mathrm{C}=-4.5--3.0)$ has a greater pore volume with radii of $9 \AA$ or less. The coefficient of correlation between the amount adsorbed at $1 \times 10^{-3} \mathrm{mmol} / \mathrm{ml}$ (Figs. 1-4) and the pore volume for pores with radii of $9 \AA$ or less (Table 1 ) was obtained by the least-squares method, the value being 0.98 . This suggests that, in this range of concentration, adsorption of $\mathrm{H}_{3} \mathrm{PO}_{4}, \mathrm{NaH}_{2} \mathrm{PO}_{4}$, and $\mathrm{KH}_{2} \mathrm{PO}_{4}$ takes place selectively in pores with radii of $9 \AA$ or less. Generally, the dissociation of $\mathrm{H}_{3} \mathrm{PO}_{4}, \mathrm{NaH}_{2} \mathrm{PO}_{4}$, and $\mathrm{KH}_{2} \mathrm{PO}_{4}$ provides $\mathrm{H}_{2} \mathrm{PO}_{4}^{2-}$ at $\mathrm{pH}$ values in the concentration range examined in the present study. The size of $\mathrm{H}_{2} \mathrm{PO}_{4}^{2-}$ is 4-4.5 $\AA^{16)}$. Adsorption in fine pores is dependent on the ratio of the pore diameter to the molecular diameter of the adsorbate ${ }^{17}$. The desirable ratio for adsorption is 2-1018). For $\mathrm{H}_{3} \mathrm{PO}_{4}, \mathrm{NaH}_{2} \mathrm{PO}_{4}$, and $\mathrm{KH}_{2} \mathrm{PO}_{4}$, the ratio of the pore diameter, $18 \AA$, of activated carbon to the diameters of these adsorbates was 4.0-4.5. Thus, $\mathrm{H}_{3} \mathrm{PO}_{4}, \mathrm{NaH}_{2} \mathrm{PO}_{4}$, and $\mathrm{KH}_{2} \mathrm{PO}$, can easily get into pores with radii of $9 \AA$ or less.

For the adsorbate of larger molecular size, $\mathrm{H}_{6} \mathrm{P}_{4}$ $\mathrm{O}_{13}$, the correlation of 0.93 was observed between the pore volume of pores with radii of $12 \AA$ or less (Table 1) and the amount adsorbed in the concentra. tion range below $6.3 \times 10^{-5} \mathrm{mmol} / \mathrm{m} l(\log \mathrm{C}=-4.2)$. The molecular weights of $\mathrm{H}_{3} \mathrm{PO}_{4}$ and $\mathrm{H}_{6} \mathrm{P}_{4} \mathrm{O}_{13}$ are 98 and 338 , respectively. Thus, the molecular volume of $\mathrm{H}_{6} \mathrm{P}_{4} \mathrm{O}_{13}$ would be 3.4 times as much as that of $\mathrm{H}_{3} \mathrm{PO}_{4}$ since molecular weight is nearly proportional to molecular volume ${ }^{19)}$. Assuming that the adsorbate molecules are spherical, the radius of $\mathrm{H}_{6} \mathrm{P}_{4} \mathrm{O}_{13}$ would be 6.0-6.8 $\AA$ (Calcd.). These results can consistently explain the correlation between the amount of $\mathrm{H}_{6} \mathrm{P}_{4} \mathrm{O}_{13}$ adsorbed and the pore volume in pores with radii of $12 \AA$ or less.

The relation between pore size distribution and adsorption capacity in the higher concentration range is discussed below. No correlation was observed between the amount adsorbed and the pore vol-

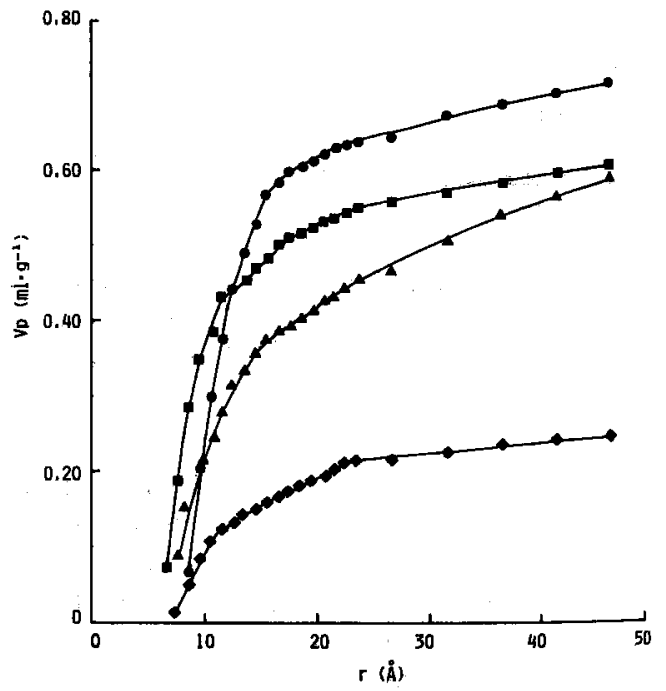

Fig. 14 Pore size distribution curves of activated carbon. $V_{p}$ : integral pore volume, $r$ : pore radius, : No.1, $\square$ : No. 2, $\Delta$ : No.3, $\bullet:$ No. 4. 
umes in pores with radii of less than 10 or $13 \AA$ in the higher concentration ranges above $3.2 \times 10^{-3} \mathrm{mmol} /$ $\mathrm{m} l(\log \mathrm{C}=-2.5)$ for $\mathrm{H}_{3} \mathrm{PO}_{4}$, and $1.0 \times 10^{-3} \mathrm{mmol} / \mathrm{ml}(\log \mathrm{C}=-3.0)$ for $\mathrm{NaH}_{2} \mathrm{PO}_{4}$ and $\mathrm{H}_{6} \mathrm{P}_{4} \mathrm{O}_{13}$. The amount adsorbed is the greatest in activated carbon No. 3 in these concentration ranges. It can be seen from Fig. 14 that the pore volume in pores with radii of $9 \AA$ or less is small while that in those with radii of $9 \AA$ or more is relatively large in activated carbon No. 3. According to the potential theory of Polanyi, the filling of adsorbent pores with adsorbate takes place in the smallest pores first and then in greater ones sequentially ${ }^{20,211}$. In the adsorption of sodium dodecylbenzenesulfonate on activated carbon, the pores with $10 \AA, 15 \AA$, and $20 \AA$ radii were successively filled with dodecylbenzenesulfonate in this sequence as the adsorption proceeded ${ }^{22)}$. It is also suggested that adsorption takes place in small pores when the concentration is low and that it is accelerated in larger pores after the smaller ones are saturated as the concentration increases.

It can be concluded from these findings that $\mathrm{H}_{3} \mathrm{PO}_{4}, \mathrm{NaH}_{2} \mathrm{PO}_{4}$, and $\mathrm{KH}_{2} \mathrm{PO}_{4}$ are first adsorbed into the small pores of activated carbon which have radii of $9 \AA$ or less and then, after the saturation of these pores, adsorbed into those with radii above $9 \AA$. Each of the adsorption isotherms for activated carbon samples Nos. 1, 3, and 4 has an inflection. This may be due to the fact that the adsorbate is adsorbed into pores with radii greater than $9 \AA$ in the higher concentration range after those with pore radii of $9 \AA$ or less are saturated in the lower concentration range. On the other hand, no inflection was observed in the adsorption isotherm for activated carbon No. 2. It is obvious from the pore size distribution curve (Fig. 14) that the pore volume in pores with radii of $9 \AA$ or less is greater in activated carbon No. 2 than in other activated carbons. This leads to the conclusion that, with activated carbon No. 2, most of the adsorbate molecules were adsorbed in these small pores.

3 Relation between equilibrium adsorption and $\mathrm{pH}$ value

The amount of dodecylbenzenesulfonate adsorbed on activated carbon is sharply increased at $\mathrm{pH}$ 2.7-3.7, which is larger than the pKa value of dodecylbenzenesulfonate by a figure of $2-3^{23}$. It is also suggested that the amount adsorbed undergoes a change at a $\mathrm{pH}$ value larger by a figure of about 2 than the pKa value of benzoic acid derivatives adsorbed on activated carbon ${ }^{24)}$. The amount ${ }^{2} \mathrm{H}_{3} \mathrm{PO}_{4}$ adsorbed on activated carbon was changed sharply at $\mathrm{pH}$ values which were larger by 2 to 3 than the $\mathrm{pK}_{1}$ (2.12) and $\mathrm{pK}_{2}(7.21)$ of $\mathrm{H}_{3} \mathrm{PO}_{4}$. This is nearly consistent with the results previously reported ${ }^{23,24}$. The amount of phosphate adsorbed comes to its greatest value at $\mathrm{pH} \mathrm{1-4}$ for adsorbents such as synthetic aluminium silicate ${ }^{5)}$ and ion exchange resin". The adsorption of phosphate is enhanced at $\mathrm{pH} 1-4$ in still other types of adsorbents ${ }^{7,25,26)}$. The differences in the $\mathrm{pH}$ values suitable for phosphate adsorption onto activated carbon and those for other adsorbents are considered to arise from the differences in adsorption mechanisms. Since the $\mathrm{pH}$ value of the first-and second-step treated water is in the region of 5-727,28), activated carbon No. 2 can effectively adsorb and remove phosphate in the waste water.

4 Rate of adsorption

Since the adsorption rate is slower in liquid phase adsorption than with gas phase adsorption, one should select the adsorbent after adequately understanding its adsorption properties in the subject system. The adsorption mechanism of porous adsorbents such as activated carbon has been considered to consist of the following four steps: (1) diffusion of adsorbate through the liquid toward the adsorbent surface, (2) diffusion of adsorbate in the boundary layer over the adsorbent layer, (3) diffusion of adsorbate in the pores within the adsorbent, and (4) adsorption reaction ${ }^{29}$. The rates of steps (1) and (4) are higher than those of step (2) and step (3). The influence of step (2) can be eliminated by adequate stirring, and step (3) acts as the rate-determining process in such a case. Thus, the adsorption rate can be analyzed on the basis of the conditions of rate-determination by intraparticle diffusivity. The intraparticle diffusivity serves as an important index when the batch adsorption method is switched to the column method. The diffusion coefficients of $\mathrm{KH}_{2} \mathrm{PO}_{4}(0.04997 \mathrm{~mol} / l)$ and $\mathrm{NH}_{4} \mathrm{H}_{2} \mathrm{PO}_{4}(0.04983 \mathrm{~mol} / l)$ are $10.816 \times 10^{-6}$ and $10.891 \times 10^{-6}$ $\mathrm{cm}^{2} / \mathrm{sec}$, respectively ${ }^{30}$. The values of $D_{1}{ }^{\prime}$ are $1 / 100-1 / 5$ of the diffusion coefficient of phosphate in water. With activated carbon, the $D_{1}^{\prime}$ values of phosphate are $100-10,000$ times as large as those of methylene blue and sodium dodecylbenzene sulfonate ${ }^{31}$. This is due to the fact that the molecular size of phosphate is smaller than that of sodium dodecylbenzene sulfonate and methylene blue. The fact that 
the $\mathrm{Di}_{i}^{\prime}$ values of phosphate adsorbed on activated carbon No. 3 are 5-30 times as large as those for the other activated carbons leads to the conclusion that activated carbon No. 3 is the best adsorbent for phosphate removal from the point of view of adsorption rate.

5 Relation between intraparticle diffusivity and pore size distribution

The relation of $D_{1}^{\prime}$ to pore size distribution was examined and it was found that there was a correlation of 0.90 , on the average, between $D_{1}{ }^{\prime}$ and the pore volume for pores with radii of $15-50 \AA$ when $\mathrm{H}_{3} \mathrm{PO}_{4}, \mathrm{NaH}_{2} \mathrm{PO}_{4}$ or $\mathrm{KH}_{2} \mathrm{PO}_{4}$ was used as the adsorbate. For adsorbate $\mathrm{H}_{6} \mathrm{P}_{4} \mathrm{O}_{13}$, a correlation of 0.71 was observed between $D_{1}{ }^{\prime}$ and the pore volume for the $15-50 \AA$ radius. It is known that the transitional pores $(15-16 \AA<r<1000-2000 \AA)$ of activated carbon act as passages for the adsorbate molecules to reach the adsorption sites $^{18}$.

It is suggested that pores with radii of $8-30 \AA$ and $20-100 \AA$ have a great influence on the rate of adsorption to activated carbon of methylene blue and sodium dodecylbenzene sulfonate, respectively ${ }^{31}$. The present results show that the rate of phosphate adsorption to activated carbon increases with the volume of the pores having radii of $15-50 \AA$ or $15-100 \AA$.

\section{CONCLUSION}

Since an activated carbon adsorption process is utilized for waste water treatment, it is necessary to obtain detailed data on the adsorption-removal of phosphate by activated carbon. The adsorption isotherms of $\mathrm{H}_{3} \mathrm{PO}_{4}, \mathrm{NaH}_{2} \mathrm{PO}_{4}, \mathrm{KH}_{2} \mathrm{PO}_{4}$, and $\mathrm{H}_{6} \mathrm{P}_{4} \mathrm{O}_{13}$ were expressed by the Freundlich equation. The inflection in log-log plot of the isotherms indicated a difference between the pore size distribution of adsorption space in low and high concentrations. The adsorption of phosphate on activated carbon was a physical process rather than an electrostatic process. A correlation coefficient of 0.98 was observed between the amonuts of $\mathrm{H}_{3} \mathrm{PO}_{4}, \mathrm{NaH}_{2} \mathrm{PO}_{4}$, and $\mathrm{KH}_{2} \mathrm{PO}$ adsorbed and the pore volume for pores with radii of $9 \AA$ or less. The amount of $\mathrm{H}_{3} \mathrm{PO}_{4}$ adsorbed was the greatest in the range of $\mathrm{pH} 5-6$. The values of intraparticle diffusivity were $1 / 100-1 / 5$ of the diffusion coefficient of phosphate in water. The rate of phosphate adsorption on activated carbon increased with the increase of volume of the pores having radii of $15-50 \AA$ or $15-100 \AA$.

\section{REFERENCES}

1) Okada, M. and Sudo, K. : Effect of phosphorus on growth of algae (in Japanese) Yosui to Haisui, 22, 891-906 (1980).

2) Goda, T.: Phosphorus in the environment (in Japanese), Yosui to Haisui, 22, 871-883 (1980).

3) Yoshida, I., Takeshita, R. and Ueno, K. : Adsorption of phosphate ion by various ion exchange resins loaded with iron (III) (in Japanese), Nippon Kagaku Kaishi, 220-226 (1980).

4) Honda, Y., Nakano, N.I. and Nakano, M.: Activated carbon beads for first-aid antidote (in Japanese), Farumashia, 21, 414-417 (1985).

5) Takimoto, K., Fujita, A. and Tsuda, S. : Adsorption of phosphate on synthetic alumina possessing Lewis-acid sites, Bull. Chem. Soc. Jpn., 50, 2479-2480 (1977).

6) Shimabayashi, S., Fukuda, H., Aoyama, T. and Nakagaki, M.: Adsorption of phosphate ion by hydroxyapatite in water, Chem. Pharm. Bull., 30, 3074-3081 (1982).

7) Takeshita, R., Yoshida, I. and Ueno, K. : Adsorption behavior of phosphate ion or the iron (III) complex of a chelating resin, Bull. Chem. Soc. Jpn., 52, 2577-2580 (1979).

8) Ogawa, T.: Phosphorus removal from effluents discharged from night-soil treatment plants (in Japanese), Yosui to Haisui, 22, 964-975 (1980).

9) Annaka, T.: Removal of phosphorus from waste water (in Japanese), Yosui to Haisui, 22, 959-963 (1980).

10) Japanese Industrial Standard, KO102.: Testing methods for industrial waste water (in Japanese), 86-87 (1974).

11) Dryden, C.E. and Kay, W.B.: Kinetics of batch adsorption and desorption, Ind. Eng. Chem., 46, 2294-2300 (1954).

12) Boki, K.: Studies on the adsorption removal of hydrogen sulfide gas, Static and dynamic adsorption characteristics of hydrogen sulfide in gaseous phase on porous activated carbons and zeolites (in Japanese), Jap. J. Hyg., 32, 482-493 (1977). 
13) Brunauer, S., Emmett, P.H. and Teller, E. : Adsorption of gases in multimolecular layers, J. Am. Chem. Soc., 60, 309-319 (1938).

14) Paterson, S.: The heating or cooling of a solid sphere in a well-stirred fluid, Proc. Phys. Soc. (London), 59, 50-58 (1947).

15) Tokunaga, S. and Shiokawa, J. : Adsorption of orthophosphate on a synthetic silica-alumina, Bull. Chem. Soc. Jpn., 53, 402-406 (1980).

16) The Chemical Society of Japan (ed.). : Kagaku Binran Kisohen II, 2nd Ed. (in Japanese), p. 1199-1200, Maruzen, Tokyo (1975).

17) Gregg, S.J. and Sing, K.S.W. : Adsorption, Surface Area and Porosity, 2nd ed., p. 207, Academic Press Inc., London (1982)

18) Kitagawa, M., Yanai, H., Kokubu, S. and Eguchi, R. (eds.).: Kasseitan Kogyo (in Japanese), p. 43-44, Jukagaku Kogyo Tsushinsha, Tokyo (1975).

19) Urano, K. and Nakai, T.: Intraparticle diffusivities in liquid phase adsorption under nonlinear equilibrium (in Japanese), Nippon Kagaku Kaishi, 1486-1491 (1976).

20) Ponec, V., Knor, Z. and Cerny, S. : Adsorption on Solids, (English translation ed. by Smith, B.A. and Adams, N.G.), p. 372-373, Butterworths, London (1972).

21) Abe, I., Hayashi, K., Kitagawa, M. and Urahata, T.: Characteristic adsorption curve on activated carbon in gas and liquid phases (in Japanese), Nippon Kagaku Kaishi, 830-835 (1979).

22) Kawazoe, K., Suzuki, Y. and Sugiyama, I. : Studies on removal of organic contaminants from waste water by activated carbon (in Japanese), Seisan Kenkyu, 27, 104-107 (1975).

23) Abe, I., Hayashi, K. and Kitagawa, M.: Adsorption of sodium dodecylbenzenesulfonate on activated carbon (in Japanese), Nippon Kagaku Kaishi, 1905-1910 (1969).

24) Getzen, F.W. and Ward, T.M. : A model for the adsorption of week electrolyte on solids as a function of $\mathrm{pH}$, J. Colloid Interface Sci., 31, 441-453 (1969).

25) Kobayashi, E., Uematsu, K., Sugai, M. and Higuchi, M.: Adsorption of phosphate ions by the titanium (IV) oxide monohydrate-active carbon complex (in Japanese), Nippon Kagaku Kaishi, 1319-1325 (1981).

26) Ohashi, K., Saito, T., Sai, A., Motojima, K. and Yamamoto, K. : Adsorption behavior of orthophosphate onto activated carbon loaded with molybdenum (IV) or iron (III), Bunseki Kagaku, 31, 367-374 (1982).

27) Asada, H. and Seki, K. : Phosphorus removal from secondary effluent by bone-char nucleation (in Japanese), Yosui to Haisui, 22, 937-944 (1980).

28) Sekikawa, Y.: Simultaneous removal of phosphorus and other complements by a multi-functional process (in Japanese), Yosui to Haisui, 22, 945-950 (1980).

29) Nakai, T., Tatsumi, K., Sato, Y. and Yumoto, H. : Adsorption treatment of waste water from a synthetic dye factory, I. Adsorption characteristics for actual waste water (in Japanese), Mizu Shori Gijutsu, 19, 31-40 (1978).

30) The Society of Chemical Engineers, Japan. : Bussei Teisu VI (in Japanese), p. 246, Maruzen, Tokyo (1968).

31) Kitagawa, H.: Preparation of active carbon from phenol-formaldehyde resin (in Japanese), Nippon Kagaku Kaishi, 1145-1150 (1972). 


\title{
活性炭によるリン酸塩の吸着除去
}

\author{
近幾大学薬学部 \\ 坊木 佳 人・棚 田成 紀 \\ 徳島大学医学部公衆衛生学教室 \\ 三 好 保 - 山崎亮 治 - 大 谷信 弘 - 田村 隆 教
}

活性炭吸着工程が庭水処理施設に組み込まれているにもかかわらず,活性炭によるリン酸塩の吸着除去に関する研究 が少ない。吸着除去効果を上げるためには，吸着平衡と吸着速度に対する知見を得る必要がある。

吸着質 $\mathrm{H}_{3} \mathrm{PO}_{4}, \mathrm{NaH}_{2} \mathrm{PO}_{4}, \mathrm{KH}_{2} \mathrm{PO}_{4}, \mathrm{H}_{6} \mathrm{P}_{4} \mathrm{O}_{13}$ の吸着等温線は Freundlich 式て整理された。吸着等温線の平衡碞度

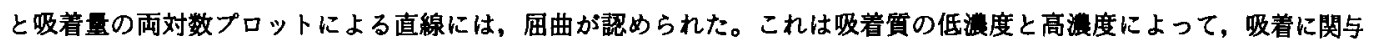
する細孔径が，それぞれ異なるためであると考えられた。活性炭によるリン酸塩の吸着は静電的な力よりもむしろ物理 的な力によるものであった。 $\mathrm{H}_{3} \mathrm{PO}_{4}, \mathrm{NaH}_{2} \mathrm{PO}_{4}, \mathrm{KH}_{2} \mathrm{PO}_{4}$ の吸着量と細孔半径 9 \&以下の細孔容程との間には, $0.98 の$

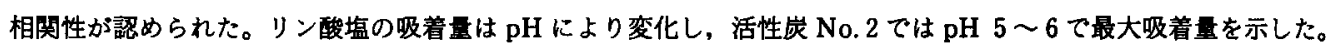

リン酸塩の活性炭に対する粒内拡散係数の值は,リン酸塩の水中での拡散係数の1/100〜1/5であった。吸着速度は細

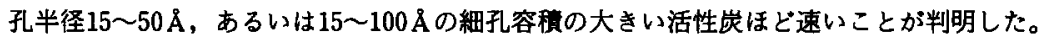

Key words: Phosphate, Activated carbon, Amount adsorbad, Adsorption rate,

Pore volume

リン酸塩, 活性炭, 吸着量, 吸着速度, 細孔容積

（受付 1986年 9 月 3 日 受理 1987年 3 月13日） 